\title{
The Effect of Work Environment and Motivation on Morale of Teacher in Ensino Básico Central Afaça, Quelicai - Timor Leste
}

\author{
Agostinho dos Santos Gonçalves \\ Accounting Economics Department, Faculty of Education \\ Instituto Superior Cristal - Dili, Timor Leste \\ santosagostinho@yahoo.com
}

\author{
Calisto Moreira \\ Accounting Economics Department, Faculty of Education \\ Instituto Superior Cristal - Dili, Timor Leste \\ calisto.moreira@yahoo.com
}

\begin{abstract}
Ensino Básico Central Afaça is Ensino Básico Central which is located away from the residential community. Thus, branch schools are rather difficult to get information directly from the center (Central School) since they are far from each other and are not transported, in addition to the lack of supervision that is routed from the authority. In addition, teachers who teach at the school ought to take a walk a few kilometers to get to their workplace (school). Since the location of schools away from the community housing, the teachers are difficult to get their basic needs. The analysis technique used in this research was a multiple linear regression analysis techniques with X1 variable (working environment), X2 variable (working motivation), and variable Y (morale). The results showed that the working environment of teachers and working motivation simultaneously has a significant effect on morale in Ensino Básico Afaça, Quelicai - Timor-Leste, where Fcount (20.106) > from Ftable (4.96) with a significance level of $0.000<0.050$. With a simultaneous correlation coefficient of 0.952 and coefficient determination $\left(\mathrm{r}^{2}\right)$ of 0.906 or $90.6 \%$. Furthermore, working environment variables (X1) and working motivation variable (X2) partially affect the morale (Y). Where, working environment obtained the value of $2.834>\mathrm{t}$ table 2.228 significant value $t$ test of 0.018 , and work motivation value of $3.206>t$ table amounted to 2.228 at a significance level of $95 \%$, or significant value $t$ test of 0.009 . Therefore, from the two variables working environment (X1) and motivation (X2), the most dominant effect on morale $(\mathrm{Y})$ is variable X2 (Motivation) where coefficients correlation of working environment (X1) on morale $(\mathrm{Y})$ of 0.900 at a significance level of 0.000 and working motivation to morale $(\mathrm{Y})$ amounted to 0.911 at a rate of significance 0.000 , with the multiple linear regression value $\mathrm{Y}=0.583+0.463 \mathrm{X} 1+0.469 \mathrm{X} 2$. Meanwhile, the correlation coefficient of the working environment and working motivation on morale obtained the value of 0.952 which $\mathrm{R}$ square of 0.906 or $90.6 \%$ and the remaining $9.4 \%$ is influenced by other factors.
\end{abstract}

Keywords: environment, motivation, morale

\section{INTRODUCTION}

The success and achievement of organizational goals in increasing the output of the organization are determined by the success in the process personnel in terms of implementing and completing an assignment, namely generating human resources (HR) which are closely related to development in the field of education. Thus the development of education is part of human resource development efforts that are held thoroughly, directed and integrated. In addition, the quality of human resources itself is aligned with the requirements needed by the development sector.

Talking about the work environment to improve the morale of teachers is inseparable from the quality of human resources because it is a major resource in accomplishing the goals and expectations aspired by relevant organizations or institutions. To achieve these expectations, it is important to carry out the development of such a system of administrative development and capable of providing opportunities for improvement of human and community quality that must be improved as well.

Since the establishment of Republica Democratica de Timor-Leste restorated on $20^{\text {th }}$ May 2002 and the stipulation of written legal jurisdiction as States Provision on $21^{\text {st }}$ May 2002 juridically and constitutionally serves as a primary reference which aspires, embolden, and motivate any law and regulation stipulated for governmental affairs and development strategy.

Within the school management, school ought to possess primary elements such as capital, infrastructure and educational facilities, and organization. The entire essential elements within school establish factual elements called working. Working is a measure taken by an individual, in this case is a teacher in certain school who performs an educational working. The individual within school community takes a role as an imperative lements in running school's management, both small-scale and large-scale management, and serves as a potential asset who able to operate, manage, and decide. Thus, individual within school's community is the one who able to operate management function such as planning, organizing, operating, and controlling to ensure the school's management will not be miscarrid at the end of the day.

The positive working environment is beneficial to avoid exhaution and tiredness of working in school organization, thus it generates a positive morale within the teacher. The primary objectives of the organization, a school in this context, is to accomplish a maximum benefit. Maximum benefit is indeed accomplished the moment the working productivity is high. Meanwhile, high productivity will be manufactured if the teacher possesses a positive morale during their assignment. Hence, it is important to establish a positive working environment.

According to the observation conducted by the authors, Ensino Básico Central Afaça is an Ensino Básico Cental which is located miles away from the residential community. Therefore, as a branch school, they are difficult to obtain information directly from the central school since they are remotely located, have no accessible transportation, and the authority performs less supervision. In addition, the teachers located in those schools are required to take a walk in miles to access the location. By locating in miles away from the residential community, thus, the teachers are difficult 
to obtain any basic necessity such as water for drinking. Pursuant to the above-mentioned issues, the authors were intrigued to conduct a research concerning on the working environment and working motivation on the morale of teacher in Ensino Básico Afaça, Quelicai - Timor Leste.

\section{Purpose of the Study}

1. To comprehend and analyze significant influence of working environment and working motivation which partially has a significant influence on the morale of the teachers in Ensino Básico Afaça, Quelicai - Timor Leste.

2. To comprehend and analyze significant influence of working environment and working motivation which simultaneously has a significant influence on the morale of the teachers in Ensino Básico Afaça, Quelicai - Timor Leste.

3. To comprehend and analyze significant influence of working environment and working motivation which dominantly influences on the morale of the teachers in Ensino Básico Afaça, Quelicai - Timor Leste.

\section{Research Hypothesis}

1. There is a significant influence between working environment and working motivation partially on morale of teachers in Ensino Básico Afaça, Quelicai - Timor Leste.

2. There is a significant influence between working environment and working motivation simultaneously on morale of teachers in Ensino Básico Afaça, Quelicai - Timor Leste.

3. There is a dominant influence from working motivation on morale of teachers in Ensino Básico Afaça, Quelicai - Timor Leste.

\section{LITERATURE REVIEWS}

Working environment plays as an important element within the school. The positive working environment will support a decent working productivity. Therefore, it also affects the prodcutivity of school. the positive working environment will activate teachers positive feeling and be avoided from exhaution and tiredness during the work. If the teacher feels exhaution, it will significantly impact the performance of teaching. According to Nitisemito (1996) in his book Personnel Management, the working environment is defined as elements prevailing arround the worker and it highly influences the worker in performing their assignment. On the other hand, Reksohadiprodjo (1992) argues that good working environment will suffice the necessity of teacher, hence teacher will automatically understand about their responsibility. From the explanation above, it can be concluded that working environment influences the performance of the teacher.

Nitisemito (1992) argues that factors contributing to the establishment of working environment are numerous. Motivation is defined as an element within the individual which encourage the individual to have a willingness in accomplishing a particular objective. Motivation is also considered as a stimulant of the individual in having a great intention and avoiding a failure. The individual possessing motivation means that the individual is on the right track in accomplishing his or her goal. In the context of psychology, the term motive is commonly defined differently from motivation.

The definition of morale according to Nitisemito (1982) is the attempt of individual in performing the assignment in a good way and full of couragement. Furthermore, he accentuates on the positive measure taken by the individual which contribute to the accomplishment of assignment. According to Municipal Personal Administration book cited from Industry and Social Psychology, morale is the individual attitude on the job assigned within the working environment (Mukijat, 1982). There are several approaches feasible to be taken to increase morale according to Nitisemito (1982) which was cited from Indrustry and Social Psychology written by Anoraga and Sri Suryati.

\section{Place and Time of Research}

III. METHODS

This research was conducted in Ensino Básico Central Central Afaça Quelicai Lama, Rua Afaça Central Quelicai District Municipiu Baucau. This research was conducted during three weeks started from $8^{\text {th }}$ to $29^{\text {th }}$ of June 2017.

\section{Population and Sample}

During any research, it is always faced with the data source called opulation and sample. But in determining the source of data, it depends on the problems posed by the researcher and the hypothesis to be tested. The population is defined as the whole subject of research, if the researcher wants to examine all elements existing in the study area then the research is a population study (Arikunto, 2002).

Samples are partly or representative of the population studied, To dilute if the subject is less than 100 , better taken all, so the research is a population study. Furthermore, if a large number of subjects can be taken between $10-15 \%$ or $20-25 \%$. Therefore, from the data that the number of employees (teachers) of the whole is one third of employees (teachers) then the population sampled in the study. According to Hair in states that the sample size according to SEM analysis (strutural equation modeling) is 100-200 (Ferdinand, 2002). In connection with the opinion of the experts above, the population in this study is the overall teacher in Ensino Básico Central Central Afaça Quelicai Antigo amounted to 13 teachers.

\section{RESULT}

\section{RESULT AND DISCUSSION}

The level of education of the teaching staff in Ensino Básico Afaça can be seen in the Table 1 below. The total of teaching staffs in Ensino Básico Afaça are 13 people. The composition of the teaching staff by gender is shown in the following Table 2. The teaching staffs of the faculty in Ensino Básico Afaça consists of several parts which further is illustrated in the following Table 3 . To prove this hypothesis, $F$ test is 
perfromed to test the significance of regression coefficients simultaneously. Based on the results of the $F$ test in accordance with the calculation SPSS for
Windows version 21 can be seen in the following Table 4.

Table 1

Teacher Education Degree

\begin{tabular}{clcccc}
\hline No & \multicolumn{1}{c}{ Degree } & Male & Female & Total & Percentage \\
\hline 1 & Master Degree & 0 & 0 & 0 & $0.00 \%$ \\
2 & Undergraduate Degree & 1 & 3 & 4 & $30.77 \%$ \\
3 & Diploma & 1 & 2 & 3 & $23.08 \%$ \\
4 & Finalist & 0 & 1 & 1 & $7.69 \%$ \\
5 & Complementare & 0 & 1 & 1 & $7.69 \%$ \\
7 & High School & 0 & 4 & 4 & $30.77 \%$ \\
\hline \multicolumn{1}{r}{ Total } & $\mathbf{2}$ & $\mathbf{1 1}$ & $\mathbf{1 3}$ & $\mathbf{1 0 0 \%}$ \\
\hline
\end{tabular}

Table 2

Teaching Staffs Gender

\begin{tabular}{cllcc}
\hline No & & Gender & Total & Precentage \\
1 & Male & & 11 & $15.38 \%$ \\
2 & Female & & 2 & $84.62 \%$ \\
\hline & & Total & $\mathbf{1 3}$ & $\mathbf{1 0 0} \%$ \\
\hline
\end{tabular}

Table 3

\begin{tabular}{clcc}
\multicolumn{5}{c}{ Years of Service } \\
\hline No & \multicolumn{1}{c}{ Years of service } & Total & \% \\
\hline 1 & $<5$ years & 2 people & $15.38 \%$ \\
2 & 6-9 years & 2 people & $15.38 \%$ \\
3 & 10-13 years & 5 people & $38.46 \%$ \\
4 & $>13$ years & 4 people & $30.77 \%$ \\
\hline \multicolumn{2}{c}{ Total } & 13 people & $\mathbf{1 0 0 \%}$ \\
\hline
\end{tabular}

Table 4

Simultaneous Hypothesis Testing

\begin{tabular}{|c|c|c|c|c|c|c|}
\hline \multicolumn{7}{|c|}{ ANOVA $^{a}$} \\
\hline & & Sum of Squares & $\mathrm{df}$ & Mean Square & $\mathrm{F}$ & Sig. \\
\hline \multirow{3}{*}{1} & Regression & 78.606 & 2 & 39.303 & 48.148 & $.000^{\mathrm{b}}$ \\
\hline & \begin{tabular}{|l|} 
Residual \\
\end{tabular} & 8.163 & 10 & .816 & & \\
\hline & Total & 86.769 & 12 & & & \\
\hline
\end{tabular}

b. Predictors: (Constant), Working motivation, working environment

$\mathrm{H}_{0}$ : The hypothesis states that the work environment, work motivation, has no significant effect on the morale of teachers.

$\mathrm{H}_{\mathrm{a}}$ : Alternative hypothesis states that the work environment and work motivation has no significant effect on the morale of teachers.

$\mathrm{F}_{\text {table }}(\mathrm{df}$ numerator $=\mathrm{k}$; denominator $\mathrm{df}=\mathrm{n}-2-1)$

$\mathrm{F}_{\text {table }}=4.96$

Criteria for acceptance or rejection of the hypothesis that: When $\mathrm{F}_{\text {count }}>4.96$, then $\mathrm{H}_{0}$ is rejected, $\mathrm{Ha}$ is accepted; and if $\mathrm{F}_{\text {arithmetic }}<4.96$, then $\mathrm{H}_{0}$ is accepted, Ha is rejected. Based on the description in table 4. above, it indicates that the value of $F_{\text {arithmetic }}$ amounted to 48.148 with a significant level of 0.000 . of $\mathrm{F}_{\text {table }}$ gained 4.96 less than $\mathrm{F}_{\text {count }}\left(\mathrm{F}_{\text {count }}=48148>4.96\right)$ and a significant value $0.000<0.05$ can be concluded that two independent variables, namely $\mathrm{X} 1$ and $\mathrm{X} 2$ (work environment and motivation) simultaneously have a significant effect on the dependent variable (morale).

Therefore, it can be said that since $\mathrm{F}_{\text {count }}=48$ $148>\mathrm{F}_{\text {table }}=4.96$ then $\mathrm{Ho}$ is rejected at the $95 \%$ confidence level with df numerator 2 and $\mathrm{df}$ denominator 11, which means a significant or significant value $\mathrm{F}$ test of 0.000 which is less than the < $5 \%$ hence $\mathrm{Ho}$ is rejected and $\mathrm{H}_{1 \text { is }}$ accepted.

Partial testing is used to test the effect of each variable independent variable to dependent variable. The partial test looks at the test results of t-test used to validate the second hypothesis $\left(\mathrm{H}_{2}\right)$ which states that Working Environment (X1) and Motivation (X2) partially effect on morale (Y). Furthermore, each partial variables can be seen from the value of $t_{\text {count }}$ obtained in t-test in the following Table 5.

Table 5

T Test

Coefficients

\begin{tabular}{|c|c|c|c|c|c|c|}
\hline \multirow{2}{*}{\multicolumn{2}{|c|}{ Model }} & \multicolumn{2}{|c|}{ Unstandardized Coefficients } & \multirow{2}{*}{$\begin{array}{c}\text { Standardized Coefficients } \\
\text { Beta } \\
\end{array}$} & \multirow{2}{*}{$\mathrm{T}$} & \multirow{2}{*}{ Sig. } \\
\hline & & $\mathrm{B}$ & Std. Error & & & \\
\hline \multirow{3}{*}{1} & (Constant) & .583 & 2.099 & & .278 & .787 \\
\hline & Environment & .463 & 163 & .469 & 2.834 & .018 \\
\hline & Work motivation & .469 & .146 & .531 & 3.206 & .009 \\
\hline
\end{tabular}

a. Dependent Variable: Morale 
The following the stages of partial hypothesis testing: partial testing between work environment on morale.

$\mathrm{H}_{0}: \mathrm{P}=0$, means that the Work Environment (X1) has no effect on morale $(\mathrm{Y})$

$\mathrm{H}_{2}: \mathrm{P} \neq 0$, means that the Work Environment $(\mathrm{X} 1)$ has effect on morale (Y)

$\alpha=0.05 / 2$ with df $(\mathrm{n}-2-1)=10$

$\mathrm{t}_{\text {table }} \quad=2.228$

$\mathrm{t}_{\text {count }} \quad=2.834$

$\mathrm{t}_{\text {hitung }}=2.834$

Based on the calculation, it obtained $t_{\text {arithmetic }}$ amounted to $2.834>\mathrm{t}_{\text {table }}$ amounted to 2.228 then $\mathrm{H}_{2}$ is accepted at a significance level of $95 \%$, or signicant value of t test of 0.018 is greater than $<5 \%$. Thus, $\mathrm{H}_{2}$ is accepted and $\mathrm{H}_{0}$ is rejected. To sum up, working Environment (X1) pastially has a significant effect on the morale (Y). Partial testing between work motivation on morale shown below:

$\mathrm{H}_{0}: \mathrm{P}=0$, means that the working motivation (X2) has no effect on morale (Y)

$\mathrm{H}_{2} \quad: \quad \mathrm{P} \neq 0$, means that the working motivation (X2) has effect on morale $(\mathrm{Y})$

$\alpha=0,05 / 2$ with df $(\mathrm{n}-2-1)=10$

$\mathrm{t}_{\text {table }} \quad=2.228$

$\mathrm{t}_{\text {count }}=3.206$
Based on the calculation, it obtained $t_{\text {arithmetic }}$ amounted to $3.206>\mathrm{t}_{\text {table }}$ amounted to 2.228 then $\mathrm{H}_{2}$ is accepted at a significance level of $95 \%$, or the significance value of $\mathrm{t}$ test for 0.009 is smaller than at < $5 \%$. Thus, $\mathrm{H}_{2}$ is accepted and $\mathrm{H}_{0}$ is rejected. To sum up, Working Motivation (X2) paretially has significant effects on the morale (Y).

From the above description, it can be concluded that the second hypothesis which states that Working Environment (X1) and Motivation (X2) partially affect the morale $(\mathrm{Y})$ teachers in Ensino Básico Afaça is proven true, namely $t_{\text {count }}$ variable Work Environment greater than $\mathrm{t}_{\text {table }}\left(\mathrm{t}_{\text {count }}=2.834>\mathrm{t}_{\text {table }}=2.228\right)$ whereas, work motivation $\mathrm{t}_{\text {count }}$ is greater than $\mathrm{t}_{\text {table }}\left(\mathrm{t}_{\text {count }}=3.206\right.$ $>2.228$ ).

This stages will analyze the correlation of both variables working environment and working motivation on morale to identify how significant the correlation of each independent varioable on morale in di Ensino Básico Afaça. The result is presented in the following Table 6.

Table 6

The Correlation of $X 1$ and $X 2$ to $Y$

\begin{tabular}{|c|c|c|c|c|}
\hline & & Morale & Environment & Motivation \\
\hline \multirow{3}{*}{ Pearson Correlation } & Morale & 1,000 & .900 & 911 \\
\hline & Environment & .900 & 1,000 & 811 \\
\hline & Motivation & .911 & .811 & 1.000 \\
\hline \multirow{3}{*}{ Sig. (One-tailed) } & Morale & & .000 & .000 \\
\hline & Environment & .000 & & .000 \\
\hline & Motivation & .000 & .000 & \\
\hline \multirow{3}{*}{$\mathrm{N}$} & Morale & 13 & 13 & 13 \\
\hline & Environment & 13 & 13 & 13 \\
\hline & Motivation & 13 & 13 & 13 \\
\hline
\end{tabular}

According to the Table 6 above, it shows that both independent variables (environment and motivation) have a significant and directional correlation on the dependent variable (morale). Where, the working environment of a teacher on morale obtaines 0.900 in a significance level of 0.000 , means strong correlation. Meanwhile, morivation on morale obtained 0.911 in a significance level of 0.000 , means directional and strong correlation. Therefore, for the third hypothesis, it indicates that between both independent variables Working environment (X1) and working motivation (X2), the most predominant variables which have a significant influence on morale is working motivation.

Multiple linear regression analysis is used to determine the correlation and influence of two or more independent variables (X1 and X2) on the dependent variable (Y) as shown in Table 7. Multiple linear regression analysis in this study aims at discovering the model correlation between working environment and motivation on morale (X1 and $\mathrm{X} 2$ on $\mathrm{Y}$ ).

Table 7

Multiple Linear Regression Analysis Results Coefficients $^{\text {a }}$

\begin{tabular}{|c|c|c|c|c|c|c|}
\hline \multirow{2}{*}{\multicolumn{2}{|c|}{ Model }} & \multicolumn{2}{|c|}{ Unstandardized Coefficients } & $\begin{array}{c}\text { Standardized } \\
\text { Coefficients }\end{array}$ & \multirow[t]{2}{*}{$\mathrm{t}$} & \multirow[t]{2}{*}{ Sig. } \\
\hline & & B & Std. Error & Beta & & \\
\hline \multirow{3}{*}{1} & (Constant) & .583 & 2.099 & & .278 & .787 \\
\hline & Environment & .463 & .163 & .469 & 2,834 & .018 \\
\hline & Motivation & .469 & .146 & .531 & 3,206 & .009 \\
\hline
\end{tabular}

a. Dependent Variable: Morale

According to the results in Table 7 , it obtain multiple linear regression model of $\mathrm{Y}=0.583+$ $0.463 \mathrm{X}_{1}+0.469 \mathrm{X}_{2}$. Thus, the interpretation of model is as follows:

1. The constant value of 0.583 indicates that if independent variables value which consists of environment (X1) and motivation (X2) equal to 0 (zero), the the value of morale is 0.583 .

2. The coefficient value of working environment of teacher (X1) equal to 0.463 . Where its coefficient has positive value and explains that the influence of working environment on morale is directional. In 
other words, the higher the value of wortking environment the higher morale within teacher. The amount of coefficient value can be concluded that if working environment increase one point level, then morale increases 0.463 point.

3. The coefficient value of working motivation of teacher (X2) equal to 0.469 . Where its coefficient has positive value and explains that the influence of working environment on morale is directional. In other words, the higher the value of wortking motivation the higher morale within teacher. The amount of coefficient value can be concluded that if working environment increase one point level, then morale increases 0.469 point.

\section{DISCUSSION \\ The Influence of Working Environment (X1) on Morale (Y)}

According to the calculation using multiple linear regression analysis, the value obtained demosntrates that working environment (X1) has positive regression coefficient result (directional) and is considered highly strong equal to 0.900 . It further illustrate that there is a strong correlation and directional between working environment and morale. In other words, the more the working environment value increase teacher morale will automatically increase and vice versa.

Working Environment of teachers partially have a significant impact on morale, with a significance value of 0.000 , compared with the level of significance of 5\%, then the value of Asymp. Sig. (2- sided) is greater than $<5 \%$. Thus, $\mathrm{H}_{2}$ is accepted and $\mathrm{H}_{0}$ is rejected, or it can be said that the work environment has a significant impact on morale in Ensino Básico Afaça , Quelicai - Timor Leste. Where, on the calculation of $\mathrm{t}_{\text {count }}$ was obtained for 2.834 bigger than $\mathrm{t}$ table amounted to 2.228 at a significance level of $95 \%$, or t test value amounted to 0.018 significantly greater than $<5 \%$ so that $\mathrm{H}_{2}$ is accepted and $\mathrm{H}_{0}$ rejected.

\section{The Influence of Working Motivation (X2) on Morale (Y)}

In the statistical calculation results, it showed that the multiple linear regression coefficient value of the regression equation model demonstrates that the working motivation (X2) showed a positive regression coefficient (directional) with a value of 0.911 . It shows a positive relationship or the direction of the category is considered very strong It can be interpreted that the more the working motivation value increase teacher morale will automatically increase and vice versa.

Working motivation $\left(\mathrm{X}_{2}\right)$ has a significant impact on morale, with a significance value of 0.000 , when compared to the level of significance $5 \%$, then the value of Asymp. Sig. (2- sided) is smaller than < $5 \%$ thus $\mathrm{H}_{2}$ is rejected and $\mathrm{H}_{0}$ is accepted, or it can be said that the motivation of work has an influence on morale in Ensino Básico Afaça, Quelicai - Timor Leste. In which, the calculation of $t_{\text {count }}$ of $3.206>t_{\text {table }}$ amounted to 2.228 then $\mathrm{H}_{2}$ is accepted at a significance level of $95 \%$, or significance value of t test 0.009 is significantly less than $<5 \%$ thus $\mathrm{H}_{2}$ is accepted and $\mathrm{H}_{0}$ is rejected, so it can be concluded that the variable work motivation (X2) has an influence on morale (Y).

\section{The Influence of Working Environment and Motivation on Morale}

According to the hypothesis testing, it indicates that both independent variables, workinbg environment (X1) and working motivation (X2) simultaneously has an influence on the dependent variable, morale. It is proven by the value of $F_{\text {count }}(20.106)>F_{\text {table }}$ (4.96) with the probability value of 0.000 , therefore research hypothesis stating that working environment and motivation simultaneously have a significant influence on morale in Ensino Básico Afaça, Quelicai - Timor Leste is proven.

On the other sides, the correlation calculation of both independent variables on the dependent variable is obtained $R$ value equal to 0.952 . the $R$ value demonstrates how significant the correlation simultaneously and directionally. It means that working environment of teacher and motivation strongly and positively correlated on morale. This directional characteristic explains that if the working environment and motivation increases, the morale of teacher increases. In addition, the determinant coefficient (R-square) is obtaines 0.906 .

The value of determinant coefficient demonstrates that the level of both variables, working environment and motivation, influence the dependent variable (morale) equal to 0.906 or $90.6 \%$. this means that the degree of contribution of both independent variables on morale is $90.6 \%$. Meanwhile, the rest of $9.4 \%$ are influenced by other factors which do not belong to the research focus and concern. Hence, to activate and encourage a positive morale of teacher in Ensino Básico Afaça, Quelicai - Timor Leste, it is important to take into account the working environment and motivation.

\section{CONCLUSION}

Working environment and motivation of teachers simultaneously have a significant effect on morale in Ensino Básico Afaça, Quelicai - TimorLeste, where $F_{\text {count }}(20.106)>$ from $F_{\text {table }}(4.96)$ with a significance level of $0.000<0.005$. With the simultaneous correlation coefficient of 0.952 and determinant coefficient $\left(\mathrm{r}^{2)}\right.$ of 0.906 or $90.6 \%$.

Work Environment (X1) and work motivation variable (X2) partially affect the morale (Y) in Ensino Básico Afaça, Quelicai - Timor Leste. Where, Work Environment obtained the value of $t_{\text {count }} 2,834>t_{\text {table }}$ 2.228 significant value $t$ test of 0.018 , and the value of work motivation obtained $t_{\text {count }} 3.206>t_{\text {table }}$ amounted to 2.228 at a significance level of $95 \%$, or significant value $t$ test of 0.009 .

From the two variables tested, the most dominant effect on morale (Y) in Ensino Básico Afaça, Quelicai - Timor Leste is variable X2 (Motivation) where the correlation coefficient Environment variables working teachers (X1) on morale (Y) obtained 0.900 at a significance level of 0.000 and work motivation variable $(\mathrm{X} 2)$ on variable morale $(\mathrm{Y})$ obtained 0.911 at a significance level of 0.000 , with the 
value of the multiple linear regression $\mathrm{Y}=0.583+$ $0463 \mathrm{X} 1+0.469 \mathrm{X} 2$. Meanwhile, the correlation coefficient Work Environment and Motivation on morale obtained 0.952 with $R$ square of 0.906 or $90.6 \%$ and the remaining $9.4 \%$ is influenced by other factors.

\section{REFERENCES}

[1] Arikunto, S. 2002. Prosedur Penelitian. Jakarta: Rineka Cipta.

[2] Moekijat. 1982. Analisis Jabatan (Job Analisis). Bandung : Alumni

[3] Nitisemito, A. S. 1996. Manajemen Personalia. Jakarta: Graha Indonesia.

[4] Nitisemito, A. S 1982. Manajemen Personalia. Jakarta: Ghalia Indonesia.

[5] Reksohadiprodjo, S., and Handoko, T. 1992. Organisasi Perusahaan: Teori, Struktur, dan Perilaku. Yogyakarta: BPFE. 